\title{
COMMENTARY
}

\section{The critical evaluation of educators' struggles in the context of Covid-19: Some theological analysis}

\author{
Magezi Elijah Baloyi \\ Department of Philosophy, Practical and Systematic Theology University of South Africa, Pretoria, South Africa
}

\section{Check for updates}

Correspondence to: Magezi Elijah Baloyi, Department of Philosophy, Practical and Systematic Theology University of South Africa, Pretoria, South Africa; E-mail: baloye@unisa.ac.za

Received: August 19, 2021;

Accepted: November 3, 2021;

Published: November 12, 2021

Citation: Baloyi, M. E. (2021). The critical evaluation of educators' struggles in the context of Covid-19: Some theological analysis. Advances in Developmental and Educational Psychology, 3(1): 121-129. https://doi.org/10.25082/ADEP.2021.01.005

Copyright: () 2021 Magezi Elijah Baloyi. This is an open access article distributed under the terms of the Creative Commons Attribution License, which permits unrestricted use, distribution, and reproduction in any medium, provided the original author and source are credited.

\begin{abstract}
Most countries have realized that education is one of the important keys to transforming their countries, and this responsibility rests hugely on the shoulders of teachers. It is concerning that the plight of teachers who are carriers of both our children's future and the future of this country seems not to be receiving the attention it deserves. Although teacher unions are many, it is questionable whether the teaching profession is receiving the protection and the encouragement it deserves in this country. The teaching profession faced many challenges in recent years. Just as we thought that the massive resignation trend that started in 2014 was coming to an end and that a period of stability was dawning, Covid-19 and the hard lockdown of 2020 happened and many of the teaching profession's serious concerns were once again thrust into the limelight. This article is concerned with the struggles of teachers during the corona period; the researcher looked at, for example, the paradox of the reopening of schools while the pandemic was raging towards its peak and how it affected teachers. Teachers were promised that they could work from home till retirement if they had comorbidities and are sixty and above of age, but they were recalled to work.
\end{abstract}

Keywords: teacher's salary, basic education, teacher's unions, counselling services

\section{Introduction}

Evans (2021) recorded that more than 1000 school children at Gauteng public schools had tested positive for Covid-19 in the first two weeks of the third wave, which was being fanned by what we know to be the Delta variant of the virus. This is true despite Matakanye's (Evans, 2021) excuse in which he indicated the lack of transparency from certain schools with regard to their following all protocols. On 08 June 2021 Mthethwa (2020) from the Daily Maverick reported that teacher unions were calling for an early closure of schools. Panyaza Lesufi was quoted as saying:

"The third wave is causing immeasurable panic and misery in our schools," he said. "To date, we have closed 20 schools due to reported Covid-19 cases. This year alone 1077 educators tested positive and the number of learners who tested positive was almost double that [1 977]." (Tshikalange, 2021).

These examples are just an indication that the education sector, particularly teachers in our public schools, are faced with several challenges that must be overcome in the wake of the pandemic. The teaching profession was seen as a very attractive and ideal profession by many people a few years ago, but things have changed. The profession is now beset by a myriad of challenges. According to Baloyi (2016), there has been growing concerns that South African teachers were leaving the profession at an ever-increasing and, indeed, alarming rate since 2014. This was echoed by the spokesperson for the South African Council of Educators who stated, "We are very much aware that teachers in the prime of their careers are leaving" (Mkhize, 2015). Nkosi's (2015) report indicated that 4,600 teachers had resigned in November 2014 alone. The Education MEC for Gauteng, Panyaza Lesufi, articulated this concern in Serrao's report (Serrao, 2014). Just as it seemed as if this exodus was becoming something of the past, the Covid-19 pandemic and lockdowns became our new reality and brought in its wake a different set of challenges to the teaching profession. It is known that almost everyone, every profession was affected by the lockdown, but for the sake of this study, the researcher's focus is confined to teachers and the education sector. The researcher agrees with the fact that the lockdowns brought about by the corona virus had a significant negative impact on teaching and learning (Burgess \& Sievertsen, 2020). Mahaye (2020) confirmed that "South Africa has the fourth largest number of learners affected by COVID-19 in Africa". This talks to the challenges that teachers in particular, face. 
It is the aim of this article to explore and unveil the challenges that teachers particularly in the basic education sector in South Africa are facing as a result of the Covid-19 pandemic. The researcher is not going to argue that the church or theology must take over the role of government in resolving the challenges faced by teachers, but to share a theological perspective which might assist the government in shaping the way forward. It should be noted that practical theology can not afford to be silent when challenges of any form are engulfing God's people. As much as other disciplines share in this challenge, theology will be irresponsible to fold its arms while the situation demands its contribution. This is part of what Cone (1975) said when he argued that God is always on the side of the poor and oppressed. It is true that the outbreak of Covid-19 has completely altered almost every aspect of life, education included. The president of the country, Cyril Ramaphosa, eventually declared an immediate closure of schools when he spoke to the nation on Sunday, 27 June 2021: "Schools will start closing from this Wednesday, the 30th of June, and all schools will be expected to be closed by the end of the week, on Friday. Contact classes at tertiary institutions will end by Wednesday, the 30th of June, with limited access to the institutions. Residences will, however, remain open, ..." (Mabuza, 2021). With all these in mind, the intention of this article is to grapple with the challenges that South African educators face in the context of Covid-19.

\section{Why (practical) theology}

Without undermining the roles that were played by other disciplines in the lives of struggling teachers, it is the researcher's understanding that the challenges faced by teachers demand in a spiritual sense that theology also comes on board. Working hand in hand with and acknowledging authors from other fields like psychology, sociology, and others will help to address people's challenges in totality. Such authors include Domingo et al (2015), Batya \& Becker (2015), etc. Shilubana (2019) quoted Baloyi "If God of theology is God of the world, then theology will be questioned if it does not adequately respond to people in their situations and contexts". There is much in the statement that emphasises that Practical Theology is a "restless" theology; it is always moving within the lives of people within their immediate situations. Veiling (2005) articulated that while it tries to debate the formalities in academic circles and papers, Practical Theology continually finds itself "without a home". This is one branch of theology that cannot afford to fold its arms when people are still faced with challenges, hence it attempts to move from problems to praxis. Practical theologians Bonino (2004), Lartey (1997), Clinebell (1984) and Steyn \& Masango (2011) agree that unless the practical theologian is mindful of the contexts of those they intend to address, the theologian runs the risk of being irrelevant.

\section{Background}

Just like in the rest of the world, corona virus took South Africans by surprise when it landed in the country through the first person who arrived back in KwaZulu-Natal from a visit to Italy. This deadly, infectious virus forced a quick closure of almost everything in the middle of March 2020 , including the education sector with the aim of slowing its spread.

Cleophas (2020) says:

"In South Africa, classroom pedagogy and online teaching and learning take place in a society that has been classified, according to a recent research-based study, Inequality Trends in South Africa, as the most unequal in the world. This finding was made three months before a national lockdown began on March 26. This means South Africans entered the lockdown period in unequal economic conditions and now experience it as such."

After four to five months of lockdown, online thinkers advised that for education to continue, digital teaching and learning which is part of the fourth industrial revolution was the route to take, hence departments and government embarked on making it work (Mishra et al, 2020). This implied that tools like Zoom, Teams, Google meet, webinars and others had to be deployed.

For Lederman (2020), embracing the digital academic experience was not by choice. Covid19 forcefully pushed educational institutions, departments of education and government into a digital academic experience whether they were prepared or not. Mishra et al (2020) indicate that it cannot be denied that the normal or traditional system of teaching and learning right from elementary to tertiary level had all but collapsed during the lockdown. Considering the above, Lederman (2020) begs the question, "Will a shift to remote teaching be boon or bane for online learning?" There are many confirmations that teachers are amongst the working groups who are most vulnerable to the ravages of this pandemic. Ishmail (2020), in her article confirms that teachers are facing strain in their efforts of trying to cope with the 2021 first quarter reopening of 
the schools while the pandemic is still raging. This is even worse for the teachers in the Basic Education sector whose learners are still too young to be able to cope with online teaching, particularly those learners in poor schools that depend on a government subsidy.

\section{Some of the challenges faced by basic education teachers}

\subsection{Additional work without additional salary}

The annual salary increase for teachers has been a bone of contention for some years now. This notion was confirmed by the Head of Human Resources of the KwaZulu-Natal Education Department who argued that the department should improve the working conditions as well as the remuneration of educators in order to keep them in the profession since many of them have started seeking for greener pastures elsewhere (Mkhize, 2015). Although this was before the arrival of the corona virus, there is evidence that teachers already had problems regarding their salaries as far back as 2014, meaning the lockdown only served to exacerbate the existing problems in the sector. It was mentioned that teachers would have to assist in ensuring that learners were distanced, their hands sanitized, that they were wearing masks and that they were accompanied to toilets and their hands washed. This is an added workload that was not agreed upon in their performance agreements. The next subsection echoes the additional work of counselling children as indicated below. Jacobus Cilliers, Brahm Fleisch, Cas Prinsloo and Taylor's (2020) article entitled: "How to Improve Teaching Practice" amongst others, can be used as guideline to what should be done when new work is added into teaching. The picture accompanying the article by Ishmail (2020) shows a teacher busy sanitising a learner - this takes considerable time, which should have been devoted to what the teacher has been hired to do, which is to teach.

\subsection{Counselling in schools}

The lockdown situation undoubtedly leaves educators with much to think about; firstly, it is their own health that is at risk when schools reopen. Secondly, it is their responsibility to take the lead in the new normal but additionally they must now also ensure the safety of the returning children. These uncertainties engulfing educators already signal a need for them to receive counselling from professionals, unless the DBE is ready to use underperforming teachers in an uncertain environment without any basic support. For school headmasters it is also about thinking how to plan and juggle their work around limited resources as some staff would not be returning to work due to comorbidities. The assertion that online teaching is also a source of psychological stress is articulated by Wadhwa (2020). As much as Naman Wadhwa agrees with the strong need for counselling, he also argues that government should ensure that it makes available the necessary digital resources, especially to poor households in rural communities. Cheating among learners could become a common occurrence in the online environment and this brings an added challenge for teachers (Wadhwa, 2020).

According to Ndaba (2020), the Minister of Education, Angie Motshekga confirmed that high levels of psychological and emotional stress and restlessness were already prevalent among school communities regarding the perceived spike or peak of the outbreak of infections. This includes teachers, learners as well as parents. In the schooling context, this already indicates a demand for counselling for both teachers and pupils. There is much truth in what Suprinyato et al. (2020) mean when saying: "Counselling services in Covid-19 pandemic need to be optimized because all students experience various problems. Problems that arise in students are academic, personal, social, and career.' It was noted that there was resistance from some teachers towards the Covid-19 vaccine which they are expected to take. Monama (2021) reported that the Department of Basic Education was trying to work with faith-based organisations because, "Gauteng announced that nearly 9000 teachers and support staff did not want to be vaccinated". The fears and doubts that caused this resistance cannot simply be ignored since many of the underlying reasons might need to be addressed instead of just forcing them to be vaccinated.

There is a need for guidance and counselling services because learners from foundation phase to secondary school and even students at tertiary level are experiencing problems. The variety of issues experienced by students are mental health problems, misinformation problems, educational problems, and a lack of coping strategies (Pragholapati, 2020). The eNCA news channel (2020) is in possession of the report in which Minister Angie Motshekga was quoted as 
saying: "Teachers should induct, orientate and counsel the learners who have already arrived at schools with the new Covid-19 environment".

The problem with the minister's statement, however, is that she places the responsibility on teachers to do counselling without such teachers having received any training to do so. The minister has previously acknowledged that teachers too are experiencing emotional and other challenges and yet, she expects teachers to act as counsellors to learners who are experiencing varying degrees of emotional and other trauma. The question begs, what do we do with qualified counsellors if teachers are expected to fulfil their roles. Does the Department of Basic Education now wish to nullify the counselling qualification and confer it on teachers? This might create serious controversy. It was never before expected of educators to have counselling as part of their qualification. All these unchallenged controversies will inform the results of the children at the end of the year since the unresolved situation is very likely to impact on the performance of educators. Recently, the president touched on teachers' woes again in his televised speech on 09 January 2021 when he could not say whether the planned reopening of schools for 27 January 2021 would proceed or not. Njilo (2021) sums up the uncertainty in her report in the Sunday Times as just adding to the dilemma in which teachers find themselves since those who are still on vacation and those who have gone to their rural homes for the school holidays do not know whether they should return to work or not. She was quoted as saying: "As schools and other educational institutions prepare to begin the new year, there is understandably concern about whether this is advisable in the midst of a second wave of infections". This kind of statement affects teachers as they have to plan their return to work or not. According to (Payne, 2021), this statement was contradicted by Mr Elijah Mhlanga, spokesperson for the DBE, who argued that (the reopening of) schools was a solution.

\subsection{Technological online teaching without special training for teachers}

Though from an Indonesian context, Putri et al. (2020) confirm that online teaching places extra pressure on teachers. Reilly (2020) quotes a teacher as saying: "I've not been trained to do any of this, and I don't want my students to be at a loss because I am in uncharted territory". The teacher in question argues that she is not an online teacher and it is this frankness about the situation in which teachers find themselves that needs the attention of the department and government.

The truth is that to expect teachers to do justice to teaching through methods that they were not trained in, is not only unfair, but also against labour practices. A good start in addressing the issue of teachers' enhancement of technologies will be to try and address it in the form of the following question which Glutsch et al. (2020) did in the German context:

"How do school computer technology (e.g., ICT tools available), teachers' professional competence (e.g., technological pedagogical knowledge, TPK), and opportunities for developing digital competence to which the teachers were exposed during training affect their successful mastery of such challenges?"

Considering this question, it should, however, be noted that in the South African context, there are many senior teachers whose training some 30 to 35 years ago did not even include computers as part of their curricula, but they are now expected to be competent in online teaching. It is this kind of expectation that will compromise learners' futures as senior teachers (and in all probability many younger teachers too) are grappling with teaching online without ever having received any training in this regard. I cannot agree more with Plitnichenko (2020), in her article entitled " 10 Challenges of E-Learning during COVID-19" when she says: "It's hard for teachers, students, and parents to start using a learning management system or any other digital tool out of nowhere without additional training." It is a very strange expectation that teachers are supposed to move their classes online right away having no additional training and with no extra budget (Plitnichenko, 2020). There is evidence that even first world countries like Germany, France and Italy are still lagging behind in their schools regarding the expected information and communication technologies (ICT) transformation progress (Duckworth et al., 2019).

Potter et al. (2020) agree that online teaching involves working through a whole set of challenges relevant to technology in teaching. The question that can be raised in this context, is whether our teachers who were traditionally trained to teach in physical classes are equipped to cope with the demands of the technology, let alone the purchasing of equipment which is the task of the department. Rapanta et al. (2020) are in agreement that the majority of teaching staff even in the basic education sector are expected to prepare and deliver their classes away from formal classrooms, with all the practical and technical challenges this entails, and often without proper technical support. Although these authors did not refer to the South African context, their 
sentiment was echoed several times in South Africa, especially in respect of those teachers with comorbidities since they should avoid the formal school setting at all costs.

\subsection{The need to address dilemma/challenge of replacing outgoing teachers}

Ngqakamba (2021) is of the opinion that it is not going to be easy for the department to fill the vacancies created by teachers who passed away as well as those who resigned due to their comorbidities. While the expectation of each class is to have a teacher at the reopening of schools, the sad reality is that teachers and their principals are on their own in this regard. They will have to ensure that those classes where teachers have died or resigned, are taken care of. Writer (2021) indicated that a presentation was submitted to parliament in which National Treasury and the South African Teachers Union (SAOU) warned about further teacher shortages while classes are already overcrowded. In other words, some of the schools are expected to produce quality teaching and learning, without enough teachers to ensure that it happens. The is obviously going to take its toll on the surviving teachers, adding to their existing fears and anxiety and all other human challenges they already face because of the pandemic.

Cruywagen (2020), Daily Maverick reporter indicates that 1700 teachers died in South Africa after contracting Covid-19, while in just one week during December 2020, 32 teachers died of the virus. Basic Education spokesperson, Elijah Mhlanga confirmed the grief of the teaching fraternity in December 2020 after the loss of so many teachers during that time and the concern this raised. In her latest report dated 14 February 2021, the Minister of Basic Education, Mrs Motshekga indicated that 1169 teachers died of Covid-19 from December 2020 to February 2021 alone. She went on to say that from 12 February 2021, 159 deaths of teachers had already been reported (Matangira, 2021).

According to Shange (2020), a massive problem is looming in 2021 for education. Shange is of the opinion that the second and possibly third waves of the pandemic will wreak even further havoc in the education sector in South Africa. On 13 January 2021 between 06h00 and 07h00, the Munghana Lonene FM radio programme entitled "Tiko axi etleri" interviewed Mr Mboweni Ganyani of NATU, who emphasised that their union suggests that the reopening of schools must be postponed to mid-February 2021 after the vaccination of both teachers and children because if the reopening was to be on 27 January, teachers would still be facing many challenges. The founder of Parents Against opening of Schools, Venessa le Roux was also in full support of the delay of the reopening of schools in January 2021. It was finally reported that "the Basic Education Department has decided to delay the reopening of both public and private schools". The original opening date of 27 January 2021 was pushed to 15 February 2021, due to the outcry by teachers, unions and parents (Khubeka, 2021).

The reopening of schools remains traumatic for teachers since they are expected to return to schools in which their safety is not guaranteed. There is also no word from the DBE as to whether those educators who passed away during this time would be replaced or not.

Sobuwa (2020) reported in the Sowetan (1 July 2020) that 20000 teachers were reportedly above 60 years of age and were suffering from comorbidities which will exclude them from returning to the workspace. However, Minister Angie Motshekga in Maqhina (2020) argued that there would be no hiring or replacing of teachers. That was her response to the question by her fellow parliamentarian Nomsa Marchesi from the DA as she said: "There will be a few cases where schools will require additional classroom space to accommodate learners. On the whole, there will be no need to appoint additional educators in large numbers to accommodate social distancing" (Maqhina, 2020). Although clear that some teachers would not be able to continue with their work as planned, the minister is adamant that they would not be replaced. The implication of the minister's statement is that those left on duty would have to double their workload to serve all learners. It is against labour law to add to an employee's contracted work without negotiating or getting the employee's consent. News (2020) reported thus:

"As part of President Cyril Ramaphosa's Presidential Employment Stimulus Programme, the basic education sector aims to create 200,000 employment opportunities for Education Assistants and 100,000 for general school assistants. The BEEI seeks to address Covid-19 academic disruptions as well as some of the lingering systemic challenges. Education Assistants will support teachers in the classroom and provide extra support to learners. General school assistants will help schools to comply with Covid-19 protocols while ensuring that teaching and learning take place in a safe, secure and hygienic environment."

This project kicked off and assistants were hired but there is no mention of qualified teachers being hired. It can also be questioned why this assistance was rendered so late, as teachers had to struggle with learners since the reopening of schools in July 2020. Matiso (2020) reported 
that the Department of Basic Education indicated that they had financial challenges and was not able to employ teachers to substitute or replace those who have been granted permission to stay at home with full pay because they suffer from comorbidities which made them more vulnerable to Covid-19.

At this point the DBE reneged on its concession granted to the 22500 teachers who suffered from comorbidities. These Covid-19 were granted in accordance with Education Labour Relations Council's Collective Agreement 1 of 2020. These teachers were now expected to return to work with immediate effect (Ngqakamba, 2020). These sudden changes without proper consultation with employees just demonstrate how African leadership is lost to government. These inconsistencies make room for confusion and uncertainty and it affects teachers psychologically while the teacher unions just watch from the stands. Ngqakamba (2020) further indicated that the agreement regarding the concession to teachers had been signed by education director general Mathanzima Mweli on 30 May 2020 as well as by SADTU representative, Mugwena Maluleke. The controversies regarding teachers that the DBE has been involved in since the lockdown began is not only concerning, but can in their own cause anxiety, uncertainty and insecurity amongst teachers, which can add to the health problems of those already suffering from comorbidities. This is the type of stress which no responsible and civilised government should visit upon its citizens.

\section{Way forward}

Besides being one of the countries in which the spirit of Ubuntu should prevail to an extent where we see our teachers as our brothers and sisters, it should firstly be understood that reasonable demands relating to their work can be made on teachers. Both learners and teachers need, among other things, pastoral care and counselling and this is where practical theologians can come in by training pastors to render counselling to them. This training does not necessarily demand practical theologians to practise, but that they teach and train local pastors to do this. Any form of stress and psychological brokenness affect the health of the individual and therefore pastoral care is important in dealing with that. Frank et al. (2013) indicated as quoted in Baloyi (2016) that schools need teacher counsellors. This, however, is not common practice in South African public schools. Collaboration between the local church, school and the department of education is vital to ensure that every school is afforded the opportunity to make use of the available pastoral services or counselling. This sentiment is echoed by Lyall (Pretorius \& Van, 2003 ) in the following: "Christian counselling, based on the Word of God, can stand on its own feet and has a place and role to play in the society". Just like some churches have adopted police stations and hospitals, they should also adopt schools in their areas. Research has indicated that although we are living in a constitutional democracy which promotes freedom of religion, a bigger percentage of school children and their teachers are not averse to Christian prayer during assemblies and other public events at schools. De Vos (2015) said:

"The Federation of Governing Bodies of South African Schools (Fedsas) contends in court papers that it was perfectly acceptable for schools to embody a Christian ethos and to promote 'Christian values' (whatever this may mean) in public schools as long as the vast majority of parents desire it. (p. 1)"

This, according to Baloyi (2016), is a good opportunity for local churches to get involved in matters affecting the education of their children as well as to assist their schoolteachers. There is an undeniable need that, like in other countries, schools employ qualified counsellors who will be looking at all school challenges holistically to ensure that learners and educators receive the necessary attention they deserve. This researcher aligns himself with the truth of the research entitled: "Teacher professional quality: Counselling services with technology in Pandemic Covid-19" which clearly indicates the role of the counsellor (Supriyanto et al., 2020).

The fact that teacher unions are divided just adds to teachers' challenges. This was evident when some unions wanted schools closed while others were bowing to the DBE's call for reopening. Mthethwa (2020) gave a clear example when indicating that SADTU and Naptosa only came in later to join the call for the closure of schools which had been initiated by Cosas and EUSA. The kind of the division that exists between these unions only adds more uncertainty and confusion. Mugwena Maluleke, SADTU General Secretary was quoted as saying "The employer is always more powerful. To balance that inherently unequal relationship, there has to be a strike, to break the deadlock and go back to the table as equal partners" (Berger, 2020). Disunity has been one of the biggest sources of inequality as well as failures in a country that is still trying to get to terms with the democratic way of life. It cannot be expected of the educators to take decisions that might go against their employer on their own while they are paying members of recognised labour unions. The government is ensuring that the teachers are on how to use 
computer-based learning in order to enable them to provide learners with unlimited access to online materials (Mahaye, 2020). It will be unfair for the government to expect teachers who were working on chalkboards before the lockdown to successfully render online teaching at the switch of a button without having received any form of training in this regard.

Teachers need their untold stories to be listened to. Stapelberg (2017) is of the opinion that most teachers have internalised their emotions and that in itself, becomes a form of selfpunishment. She says: "When we looked back on how this happened, we saw self-punishment connotations in words like "falling short, afraid to speak, not paid enough, feeling punished by the government, humiliation." Although Stapelberg's research focused on the challenges faced by female teachers, much of her research talks to teachers in general and this is one such instance. Bottling up challenges and frustrations because you are not afforded a safe space in which to verbalise it is an unhealthy situation which the department must look at, particularly because only healthy workers can deliver production. It is a good narrative approach to allow teachers an ear to also share their stories to give meaning to their lives. I agree with Morgan (2005) that teachers can be assisted to avoid blaming themselves or their career when they are allowed to unfold their struggles and negotiate their meanings. During the exchanges about teachers' return to work, the voices that went up were those of union representatives, SGBs, principals and parents, but teachers themselves were not clearly heard.

Another approach, which is typically African will be to involve the wider school communities in South Africa in trying to interpret and re-interpret their experiences which could nurture a sense of achievement that can be a journey to healing. This comes from the Ubuntu spirit where collective storytelling can be empowering for all affected and involved (Stapelberg, 2017).

\section{Conclusion}

Apart from teachers having had many other challenges before the onset of the pandemic, Covid-19 has just added to the woes of the already struggling teachers. Having to take on additional workloads without salary increases is one of the problems, while the expectation of having to teach online, using technology that they had not been trained to use, is another. Teachers are also emotionally scarred as they have lost colleagues to the pandemic and many others have resigned because they suffer from comorbidities and thus fear for their lives. Unfortunately, matters are made worse when the DBE expects these very same overwhelmed and emotionally scarred teachers to counsel the traumatized learners in their care. The concern of practical theology is that something must be done if the situation and more specifically the education off our children is to be rescued. We cannot possibly expect teachers to give their best in the abnormal situation in which we currently find ourselves. Government, parents, SGBs and all other stakeholders need to act on the plight of our teachers for the sake of our country's future our children. When the education sector bleeds, the future of the country bleeds.

\section{Conflict of interest}

The author declared no potential conflict of interest with respect to the research, authorship, and/or publication of this article.

\section{References}

Asmal, L., Domingo, A. K., Volmink, J., Esterhuizen, T. M., Volmink, J., \& Seedat, S. (2015). Investigating the association between diabetes mellitus, depression and psychological distress in a cohort of south african teachers: research. African Journal of Health Professions Education, 105(12), 1057-1060. https://doi.org/10.7196/SAMJ.2015.v105i12.9843

Baldwin, N. (2020). Mothekga to face off with unions. The Star, 17 July, 2020.

Baloyi, M. E. (2016). The church's pastoral role concerning challenges faced by teachers in South-African public schools: Some practical theological perspectives. Die Skriflig 50(1), 1-9. https://doi.org/10.4102/ids.v50i1.2107

Batya, R., \& Becker L. (2005). Exploration of the narrative accounts of South African teachers working in a gang-violent community in the Western Cape. International Journal of Social Welfare, 14(2), $107-115$.

https://doi.org/10.1111/j.1369-6866.2005.00347.x

Berger, M. (2020). Teachers unions around the world clash with governments over coronavirus and school reopening plans. The Washington Post, dated 12 September 2020.

Bonino, M. (2004). An introduction to Third World theologies, Cambridge University Press, Cambridge. 
Burgess, S., \& Sievertsen, H. H. (2020). Schools, skills, and learning: The impact of COVID-19 on education.

https://voxeu.org/article/impact-covid-19-education

Cilliers, J., Fleisch, B., Prinsloo, C., \& Taylor, S. (2020). How to improve teaching practice?: an experimental comparison of centralized training and in-classroom coaching. Journal of Human Resources, 55(3), 926-962.

https://doi.org/10.3368/jhr.55.3.0618-9538R1

Cleophas, F. (2020). Covid-19 pandemic highlights challenges of online teaching and learning. Mail and Guardian, 06 August 2020.

Clinebell, H. (1984). Basic types of pastoral care and counselling, Abington Press, Nashville, TN

Cone, J. H. (1975). God of the oppressed, Seabury Press, New York.

Cruywagen, V. (2020). Call to delay reopening of schools. Maverick Citizen dated 07 January 2021.

De Vos, P. (2015). 'Religion in schools: Time to decolonize our education? Constitutionally speaking', viewed 11 November 2015. https://constitutionallyspeaking.co.za

Fraillon, J., Ainley, J., Schulz, W., Friedman, T., \& Duckworth, D. (2020). Preparing for Life in a Digital World: IEA International Computer and Information Literacy Study 2018 International Report. https://doi.org/10.1007/978-3-030-19389-8

Julia, E. (2021). Covid cases on the rise at schools in Gauteng. Daily Maverick dated 08 June 2021 and accessed on 30 June, 2021.

Knig, J., Jger-Biela, D. J., \& Glutsch, N. (2020). Adapting to online teaching during covid-19 school closure: teacher education and teacher competence effects among early career teachers in germany. European Journal of Teacher Education, 43(3), 608-622. https://doi.org/10.1080/02619768.2020.1809650

Khubeka, T. (2021). Dept confirms reopening of schools postponed by two weeks. Eyewitness news, dated 14 January 2021 and accessed on 14 January, 2021. https://ewn.co.za

Lartey, E. Y. (1997). In living colour, an intercultural approach to pastoral care and counselling, Wellington House, London

Lederman, D. (2020). Faculty Confidence in Online Learning Grows. Envisioning Higher Education's future.

Lonene, M. (2021). Tiko axi etleri. Broadcasted between 06h00 and 07h00 on 13 January, 2021.

Mabuza, Ernest. (2021). School holidays brought forward as number of Covid-19 cases rises. Sowetan Live dated 28 June, 2021.

Mahaye, N. E. (2020). The Impact of COVID-19 Pandemic on Education: Navigating Forward the Pedagogy of Blended Learning.

Mayibongwe, M. (2020). There's no need to employ extra teachers, says Angie.

Matangira, L. (2021). 1,169 teachers, 19 pupils succumbed to covid-19 since March 2020-Dept. Eyewitness News, 14 February, 2021.

Matiso, S. (2020). The Department of Basic Education is reported to be struggling to employ substitute teachers during the COVID-19 pandemic. Listeners' debate whether teachers with comorbidities should retire earlier at $11 \mathrm{~h} 00$ am in Radio 702 on 02 September, 2020.

Mishra, L., Gupta, T., \& Shree, A. (2020). Online teaching-learning in higher education during lockdown period of covid-19 pandemic. International Journal of Educational Research Open, 1, 100012. https://doi.org/10.1016/j.ijedro.2020.100012

Mkhize, N. (2015). 'Indebted teachers resign to raid their pensions', viewed 25 July, 2016. https://www.bdlive.co.za

Morgan, A. (2000). What is narrative therapy? Dulwich Centre Publications.

Mushaandja, J., Haihambo, C., Vergnani, T., \& Frank, E. (2013). Major challenges facing teacher counsellors in schools in Namibia. Education Journal, 2(3), 77-84. https://doi.org/10.11648/j.edu.20130203.13

Mthethwa, A. (2020). Teacher unions strengthen calls for schools to close mid Covid-19 peak. Daily Maverick, dated 15 July, 2021.

Njilo, N. (2021). Will they or won't they? Cyril says there is concern about reopening schools. Sunday Times dated 11 January, 2021.

Nkosi, B. (2015). Motshekga blocks re-employment of thousands of teachers. Mail and Guardian, 8 April, 2015.

Ngqakamba, S. (2020). Lockdown: It is back to school for teachers who were on leave due to comorbidities News 24 blog posted on 19 September 2020 and accessed in 02 January, 2021. https://www.news.com

Ngqakamba, S. (2021). School reopening: A rundown of some of the headaches as 15 February looms. News 24, dated 11 February, 2021.

News, S. A. (2020). Government is hiring 200,000 assistants to help in South Africa's schools - how to apply. Business tech blog posted on 10 November, 2020. https://www.businesstech.co.za

Payne, S. (2021). Schools will reopen on 27 January, as planned, says Department of Basic Education. Daily Maverick, dated 10 January 2021 accessed on 12 January, 2021.

https://www.dailymaverick.co.za 
Plitnichenko, L. (2020). 10 Challenges of E-Learning during Covid-19. Jellyfish. Blog posted on 16 August 2020 and accessed on 16 August, 2021.

https://www.jellyfish.tech.com

Practical Theological Investigation of sex addiction in Gauteng. PhD thesis in Practical Theology, UNISA.

Pragholapati, A. (2020). Covid-19 impact on students. https://doi.org/10.35542/osf.io/895ed

Putri1, R. S., Purwanto, A., Pramono, R., Asbari, M., Wijayanti, L. M., \& Hyun, C. C. (2020). Impact of the COVID-19 Pandemic on Online Home Learning: An Explorative Study of Primary Schools in Indonesia. International Journal of Advanced Science and Technology, 29(5), 4809-4818.

Rapanta, C., Botturi, L., Goodyear, P., Guàrdia L., \& Koole, M. . (2020). Online university teaching during and after the covid-19 crisis: refocusing teacher presence and learning activity. Postdigital Science and Education, 2, 923-945. https://doi.org/10.1007/s42438-020-00155-y

Reilly, K. (2020). This Is What It's Like to Be a Teacher During the Coronavirus Pandemic. Time dated 26 August 2020 accessed on 12 January, 2021. https://www.time.com

Serrao, A. (2014). 4000 teachers quit for pension payouts, accessed on 22 October, 2015. www.iol.co.za

Shange, N. (2020). Looming crisis for education department as Covid-19 hits scores of teachers over festive period. Timeslive dated 20 December, 2020.

Shilubana, M. (2018). Care and Support to sex addicts in the Evangelical Pentecostal Church.

Sobuwa, Y. (2020). 20,000 teachers report comorbidities. Unwell educators add to basic education crisis. Sowetan, 01 July, 2020.

Stapelberg, E. (2017). Exploration of a narrative pastoral approach to improve the lives of female teachers in the South African context. $\mathrm{PhD}$ with specialization in pastoral therapy, UNISA.

Sukaina, I. (2020). Teachers facing strain coping with the reopening of schools amid Covid-19. Iol News blog posted on 16 July, 2020.

Supriyanto, A., Hartini, S., Irdasari, W. N., Miftahul, A., \& Mumpuni, S. D. (2020). Teacher professional quality: counselling services with technology in pandemic covid-19. Counsellia Journal Bimbingan dan Konseling, 10(2), 176-189. https://doi.org/10.25273/counsellia.v10i2.7768

Steyn, T. H., \& Masango, M. J. (2010). The theology and praxis of practical theology in the context of the faculty of theology. HTS Teologiese Studies, 67(2), 1-7. https://doi.org/10.4102/hts.v67i2.956

Shonisani, T. (2021). Covid-19 third wave causing 'panic and misery' at Gauteng schools: Lesufi. Sowetan live dated 17 June, 2021. https://www.sowetanlive.co.za

Santiveri, M., Roa-Eguiara, A., Kühne, C., Wadhwa, N., Berg, H. C., \& Erhardt, M. Structure and function of stator units of the bacterial flagellar motor. Social Science Electronic Publishing. https://doi.org/10.2139/ssrn.3624470

Tebogo, M. (2021). Covid-19: Basic education department facing vaccine hesitancy among teachers. News 24. Accessed on 05 June 2021.

Williamson, B., Eynon, R., \& Potter, J. (2020). Pandemic politics, pedagogies and practices: digital technologies and distance education during the coronavirus emergency. Learning Media and Technology, 45(2), 107-114.

https://doi.org/10.1080/17439884.2020.1761641

Writer, S. (2021). Warning over teacher shortages and growing class sizes in South Africa. Businesstech dated 04 March, 2021.

Writer, S. (2021). Union calls for temporary school closure in South Africa. Businesstech dated 21 June, 2021. 